\title{
Pengambilan Keputusan dalam Manajemen Proyek KPR Nonsubsidi menggunakan Linier Programing
}

\author{
Uswatun Hasanah ${ }^{a}$, Susilahudin Putrawangsa ${ }^{b}$, Danang Tejo Kumoro ${ }^{c}$ \\ ${ }^{a}$ Teknik Informatika STMIK Bumigora, Jalan Ismail Marzuki, Mataram 83000, Nusa Tenggara Barat, Indonesia \\ ${ }^{b}$ Tadris Matematika Universitas Islam Negeri, Jalan Gajah-Mada No. 100, Mataram 83000, Nusa Tenggara Barat, Indonesia \\ ${ }^{c}$ Teknik Informatika STMIK Bumigora, Jalan Ismail Marzuki, Mataram 83000, Nusa Tenggara Barat, Indonesia
}

\section{INFORMASIARTIKEL}

Sejarah Artikel:

Diterima Redaksi: 04 November 2018

Revisi Akhir: 12 September 2019

Diterbitkan Online: 19 September 2019

\section{KATA KUNCI}

Perumahan Subsidi,

Keuntungan,

Linier Programming

\section{KORESPONDENSI}

E-mail: uswatun@stmikbumigora.ac.id

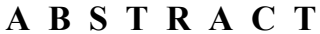

PT X merupakan salah satu pengembang perumahan subsidi dan nonsubsidi di kawasan Terong Tawah, Labu Api, Lombok Barat. Kekhawatiran PT X dalam manajemen usahanya terkait pembangunan perumahan nonsubsidi yang disebabkan karena keterbatasan sumber daya yang tersedia dan tingkat persaingan dengan para pengembang yang lain. Disamping itu, pertambahan jumlah penduduk yang semakin meningkat dapat mempengaruhi besarnya permintaan pasar akan ketersediaan rumah sehingga dapat mendorong pengembang PT X dalam mengoptimalkan profit atau keuntungan yang akan diperoleh. Linier programming dapat digunakan dalam menemukan solusi optimalisasi profit tersebut sehingga PT X dapat menentukan langkah yang tepat dalam pengambilan keputusan. Secara matematis, proses penyelesaian metode ini dilakukan secara iterasi berdasarkan pemodelan sumber daya yaitu PT X membangun perumahan nonsubsidi tipe A (40/100), tipe B (70/200) dan tipe C (200/350). Berdasarkan hasil simulasi dengan proses iterasi sebanyak empat kali dihasilkan bahwa untuk memperoleh profit secara optimal sebesar Rp. 857.140.000 maka PT X dapat membangun 71 unit rumah tipe A dengan ukuran 40 diatas luas tanah 100 meter persegi, 114 unit rumah tipe $\mathrm{B}$ dengan ukuran 70 diatas luas tanah 200 meter persegi dan 114 unit rumah tipe $\mathrm{C}$ dengan ukuran 200 diatas luas tanah 350 meter persegi.
\end{abstract}

\section{PENDAHULUAN}

Terong Tawah merupakan salah satu daerah Lombok Barat dimana Lombok Barat memiliki jumlah penduduk terpadat kedua setelah Lombok Timur yaitu jumlah penduduknya sebanyak 644.586 jiwa pada tahun 2015 [1] dengan luas wilayah 1,053.87 atau setara dengan 5,23\% dari luas daerah Nusa Tenggara Barat. Hal ini mengakibatkan jumlah permintaan KPR semakin meningkat berdasarkan keterangan dari salah satu pengurus pengembang PT X yaitu jumlah persentasi permintaan pasar di perumahan Lombok Barat sebesar $300 \%$, artinya perencanaan pembangunan perumahan yang dibangun sebanyak 1000 unit, tetapi permintaan masyarakat sebesar 3000 unit. Hal ini mengindikasikan bahwa perbandingan antara jumlah penduduk dengan jumlah permintaan pasar adalah berbanding lurus atau kelipatannya [2].

Perumahan subsidi dan nonsubsidi memiliki beberapa perbedaan misalnya dilihat dari segi harga jual, fasilitas, KPR (Kredit Pemilikan Rumah), spesifikasi, tipe bangunan, lokasi, renovasi dan harga jual kembali. Jika dilihat dari lokasi, rumah subsidi biasanya dibangun di kawasan yang baru berkembang dengan harga tanah cukup murah, sedangkan rumah nonsubsidi biasanya ditemukan ditengah kota atau daerah yang strategis, dan terjangkau. Akan tetapi, berdasarkan Peraturan Pemerintah Republik Indonesia Nomor 14 Tahun 2016 tentang Penyelenggaraan Perumahan dan Kawasan Pemukiman mendorong para pengembang untuk membangun rumah nonsubsidi di pemukiman Terong Tawah, salah satu pemukiman masyarakat yang tergolong harga beli tanah di kawasan tersebut murah [3].

KPR dimaksudkan untuk membantu masyarakat dalam hal pemilikan rumah yang disebabkan harga rumah semakin hari semakin melambung tinggi. KPR terbagi menjadi dua macam yaitu KPR subsidi dan nonsubsidi. Secara umum perbedaannya adalah penentuan jumlah kredit yang dikeluarkan yaitu KPR subsidi ditetapkan oleh pemerintah untuk masyarakat ke bawah berupa kredit ringan, bantuan dana pembangunan dan perbaikan rumah yang telah dibayarkan sebelumnya sehingga pembayaran angsurannya flat setiap tahun. Sedangkan KPR nonsubsidi 
ditentukan oleh bank berdasarkan suku bunga dan diperuntukkan kepada masyarakat berpenghasilan tinggi.

Perbedaan lainnya yaitu terkait harga jual perumahan subsidi dan nonsubsidi dengan harga jual sebanding dengan bunga yang dibebankan. Harga jual rumah nonsubsidi lebih tinggi daripada harga jual subsidi. PT X mengembangkan tipe rumah yang sesuai dengan ukuran bangunan dan luas tanah yang luas sehingga harga jual yang ditetapkan tinggi. Hal ini berkaitan dengan fasilitas yang ditawarkan setiap pengembang yaitu ruang tidur, ruang tamu, dapur dan lain-lain dengan tingkat spesikasi lebih baik dari standard spesifikasi rumah subsidi. Misalnya jika dilihat dari segi bahan bangunan, rumah nonsubsidi berbahan bata merah, rangka atap baja ringan, lantai keramik atau granit, kloset jongkok, tembok paten, menggunakan flapon dan lain sebagainya sehingga pemesan tidak merenovasi ulang atau menambah bangunan.

Pada umumnya, rumah nonsubsidi berada di tengah kota dan strategis, akibatnya jika rumah tersebut dijual kembali maka harga jualnya tinggi karena dan ukuran bangunannya minimal 36 dengan ruas jalan berupa aspal. Jika dibandingkan dengan KPR subsidi, pembangunannya telah diatur sesuai standar pemerintah maksimal ukuran bangunan 36 dan tidak diperbolehkan untuk merenovasi sebelum 2 tahun dan over kredit setelah 5 tahun [4].

Kampung Muhajirin Desa Terong Tawah merupakan wilayah pinggiran kota dan tercatat ada tujuh pengembang perumahan yang menjalankan usaha yang sama, salah satunya adalah pengembang PT X. Ada beberapa cara yang dilakukan pengembang untuk menarik minat para pembeli. Untuk memperoleh profit yang besar, hendaknya PT X memerlukan satu teknik atau cara dalam manajemen usahanya sehingga mereka mampu bersaing di pasar global dengan memperhatikan sumber daya yang tersedia seperti luas bangunan dan tanah, harga jual, biaya produksi, jumlah karyawan, persentasi permintaan pasar dan lain sebagainya.

Berdasarkan uraian yang telah dijabarkan sebelumnya maka dapat diambil rumusan masalahnya yaitu bagaimana cara PT X memanajemen usahanya terkait pengembangan rumah nonsubsidi? Penelitian ini merupakan kelanjutan dari penelitian analisis manajemen proyek pengembangan perumahan subsidi pada PT X sehingga ada beberapa batasan masalah dalam analisis pembahasannya. Batasan masalah tersebut antara lain terkait luas lahan, biaya produksi, jangka waktu pelaksanaan, permintaan pasar dan laba atas investasi atau disingkat dengan ROI. Analisis yang digunakan adalah linier programming dengan alat bantu QM.

QM adalah salah satu alat bantu komputasi pada Windows dan merupakan hasil rancangan Howard J Weiss pada tahun 1996 yang digunakan untuk membantu pihak manajemen dalam mengambil keputusan di bidang produksi dan pemasaran terkait penyusunan perkiraan biaya atau anggaran untuk produksi bahan baku menjadi produk setengah jadi atau jadi [5]. Penggunaan software ini disesuaikan dengan permasalahan dalam penelitian yaitu pengambilan keputusan dalam manajemen keuntungan proyek KPR nonsubsidi. Program ini menyediakan beberapa modul berbeda, yaitu: Aggregate Planning, Assembly Line Balancing, Assignment, Break Even/Cost-Volume Analysis, Capital Investment, Decission Analysis, Forecasting, Game Theory, Goal Programming, Integer And Mixed Integer Programming, Inventory, Job Shop Sceduling, Layout, Learning Curve, Linear Programming, Location, Lot Sizing, Markov Analysis, Material Requirements Planning, Networks, Productivity, Project Management (PERT/CPM), Quality Control, Reliability, Simulation, Statistics, Transportation, Waiting Lines, Work Measurement. Oleh karena itu, di dalam penelitian ini menggunakan modul Linear Programming untuk mencapai tujuan penelitian.

Ada beberapa penelitian sebelumnya terkait pembahasan mengenai pengembangan perumahan, yaitu penelitian yang telah dilakukan oleh Dewa Ketut Sudarsana mengenai kasus pembangunan perumahan di Taman Wira Umadui, Denpasar. Penelitian ini memberikan formulasi secara matematis mengenai jumlah tipe rumah yang akan dibangun sehingga aspek pasar terpenuhi dengan memaksimalkan profit. Diketahui, perumahan di Taman Wira Umadui membangun tiga macam tipe rumah mewah yaitu rumah tipe 60/120, tipe rumah 45/100 dan tipe rumah ukuran 36/80. Tipe rumah 60/120 artinya rumah dengan ukuran bangunan 60 dan dibangun diatas luas tanah $120 \mathrm{~m}^{2}$. Adapun sumber daya yang tersedia untuk membangun ketiga tipe rumah tersebut yaitu batasan luas tanah, biaya produksi, waktu pelaksanaan dan batasan permintaan pasar dengan tujuan menentukan jumlah tipe yang akan dibangun sehingga keuntungan yang diperoleh maksimal [6].

Perumahan ini dibangun pada tahap I dengan luas tanah 1,5 hektar dengan mendirikan tiga tipe rumah ukuran 60/120, 45/100 dan $38 / 80$ diatas luas lahan maksimal $11000 \mathrm{~m}^{2}$ dan biaya produksi tersedia untuk membangun rumah-rumah tersebut adalah 15 milyar rupiah dengan rincian masing-masing rumah secara berurutan menghabiskan dana sebesar Rp. 194.000.000, Rp. 155.000.000 dan Rp 128.000.000 dalam jangka waktu pelaksanaan 120 minggu degan ketentuan permintaan pasar sebesar 2:3:6 untuk setiap tipe rumah. Berdasarkan hasil analisis metode Simplek, ditemukan bahwa untuk mencapai keuntungan yang maksimal sebesar Rp. 7.171.000 maka dibangun rupah tipe 60/120 sebanyak 28 unit, tipe 45/100 sebanyak 17 unit dan 54 unit untuk tipe ruumah ukuran $38 / 80$.

Penelitian kedua dengan objek yang sama dilakukan oleh Rini Febri Utari dan Andi SA dengan judul optimalisasi jumlah produksi tipe rumah pada proyek pengembangan perumahan dengan menggunakan metode Simplek (studi kasus: PT Araya Bumi Malang). Berdasarkan hasil penelitiannya ditarik beberapa kesimpulan terkait pemodelan optimasi tipe rumah dengan batasan biaya produksi, permintaan pasar dengan ketentuan proporsi dari perbandingan rumah sederhana, menengah dan mewah [7]. Model fungsi tujuan dan batasan tersebut dianalisa menggunakan perbandingan dua metode yaitu metode simplek dan keadaan existing. Adapun hasil analisis menggunakan metode simplek yaitu untuk optimalisasi keuntungan PT Araya Bumi Malang maka dibangun tipe 65/144 sebanyak 387 unit untuk rumah sederhana, tipe 96/180 sebanyak 69 unit untuk rumah menengah dan tipe 
141/144 sebanyak 221/200 sebanyak 64 unit untuk tipe rumah mewah sehingga keuntungannya sebesar Rp. 78.483.073.000. Proporsi pada kondisi existing, perencanaan pembangunan yang terdiri atas sepuluh tipe rumah sebanyak 521 unit dengan keuntungan maksimal Rp. 75.092.668.000. Dengan demikian dapat dilihat bahwa menggunakan metode simplek dapat memperoleh keuntungan yang lebih besar yaitu PT Araya Bumi Malang dapat membangun empat tipe rumah saja dengan jumlah total rumah sebanyak 636 unit.

Penelitian ketiga oleh Uswatun Hasanah terkait manajemen keuntungan proyek perumahan subsidi di Terong Tawah yang merupakan penelitian sebelumnya. Penelitian ini bertujuan untuk membantu mengatasi kektidakpastian PT X dalam menentukan keuntungan dari usaha pembangunan rumah subsidi [8]. Hal ini disebabkan karena pembangunannya harus sesuai dengan standar dari pemerintah dengan ketersediaan luas tanah seluas $82 \mathrm{~m}^{2}$ dengan spesifikasi yang sesuai dengan peraturan pemerintah serta ukuran bangunan minimal 21. Adapun tipe rumah yang ditawarkan oleh PT $\mathrm{X}$ adalah tipe A (24/82), tipe B (27/82) dan tipe C (30/82) dengan harga jual masing-masing sebesar Rp. 150.000.000. ketiga rumah ini dibangun diatas luas tanah $5857 \mathrm{~m}^{2}$ dengan biaya produksi setiap rumah sebesar $80 \%$ dalam jangka waktu pelaksanaan pembangunan selama 3 bulan. Pada tahun ini melalui program pemerintah terkait program sejuta rumah subsidi, menarik minat masyarakat untuk membeli rumah tersebut karena KPR subsidi lebih murah dengan bunga flat daripada rumah nonsubsidi. Hal ini yang menyebabkan permintaan pasar meningkat drastis sampai mencapai $300 \%$, artinya dari 1000 unit yang dibangun PT X terdapat permintaan sebesar 3000 . Untuk saat ini, keuntungan bruto dari penjualan rumah subsidi sebesar $20 \%$, akan tetapi dengan memperhatikan sumber daya yang tersedia maka secara matematis dihasilkan jika PT X menginginkan keuntungan yang maksimal yaitu sebesar Rp. 34.290.000 maka sebaiknya PT X hanya membangun rumah subsidi tipe A saja yaiu $24 / 82$.

Adapun perbedaan penelitian ini dengan ketiga penelitian sebelumnya yaitu mengenai masalah sumber daya dan spesifikasi dari pembangunan perumahan. Pada penelitian pertama memiliki kesamaan dalam jumlah tipe rumah yang dibangun, akan tetapi ada beberapa sumber daya yang belum dirumuskan sebagai fungsi kendala yaitu mengenai permintaan pasar yang semakin meningkat dan persentase keuntungan atas investasi pada proyek pembangunan rumah nonsubsidi. Hal ini disebabkan karena kedua parameter dari sumber daya tersebut dapat mempengaruhi profit dari usaha pengembang. Demikian halnya dengan penelitian kedua belum mengungkapkan persentase keuntungan atas investasi pada proyek pembangunan rumah.

Adapun perbandingan dari penelitian ketiga yaitu terletak pada perbedaan kredit kepemilikan rumah (KPR). Pada umumnya KPR subsidi dibangun di wilayah pinggiran kota dengan spesifikasi rumah sesuai standar pemerintah yaitu luas ruangan lebih kecil, beratap kayu, tidak ada dapur, tanpa plafon, lebar jalan sempit tanpa jalan aspal atau paving blok dan lain sebagainya. Akan tetapi, pada tahun ini KPR subsidi dibangun dengan spesifikasi yang jauh lebih baik dan modern seperti spesifikasi KPR nonsubsidi, misalnya dilihat dari segi bangunan beratap baja, jalan aspal dan dibangun di perbatasan kota dan bahkan pembangunan KPR subsidi dan nonsubsidi berada dalam satu lahan. Perbedaan keduanya hanya terletak pada luas bangunan dan tanah sehingga PT X menyusun strategi dalam pengambilan keputusan untuk memperoleh keuntungan yang maksimal dari usaha pembangunan KPR nonsubsidi.

\section{METODE}

Adapun tahapan-tahapan dalam penelitian ini dapat digambarkan pada Gambar 1 .

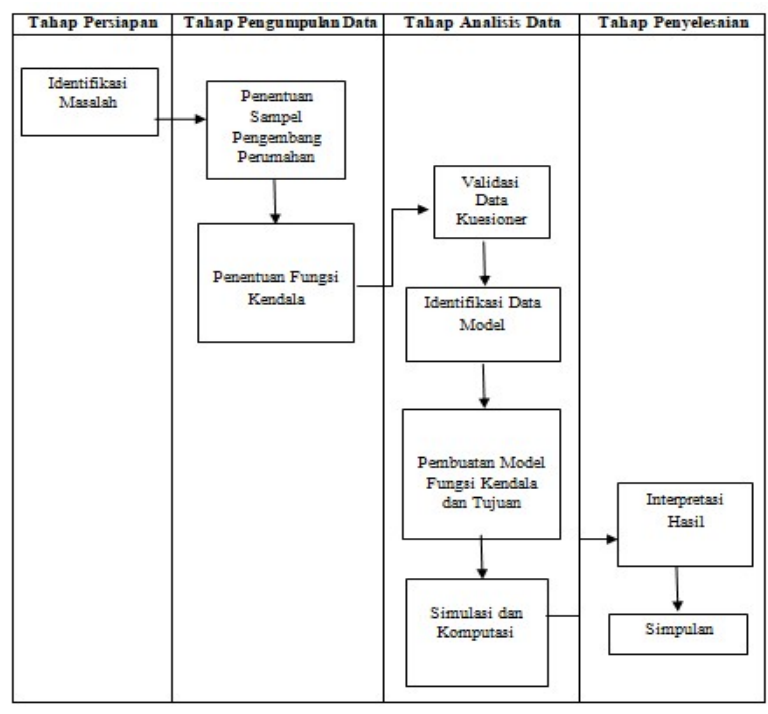

Gambar 1. Tahapan Penelitian

Gambar 1 menunjukkan bahwa tahapan penelitian ini terdiri atas pertama tahap persiapan, dalam hal ini dilakukan identifikasi masalah terkait perumahan nonsubsidi di wilayah kampong Muhajirin Terong Tawah melalui kegiatan observasi dan wawancara setiap pengembang. Tahapan kedua yaitu pengumpulan data yang terdiri atas penentuan sampel pengembang dan fungsi kendala. Terdapat tujuh pengembang yang menjalankan usaha yang sama yaitu proyek pengembangan KPR subsidi dan nonsubsidi salah satunya PT X sebagai sampel yang digunakan dalam analisis optimasi keuntungan dalam upaya langkah pengambilan keputusan. Melalui hasil observasi dan wawancara mendalam, PT X adalah salah satu PT yang memiliki pengaruh besar dalam usaha proyek pembangunan KPR subsidi dan nonsubsidi di wilayah NTB sehingga ada dua objek penelitian yang bisa dianalisis yaitu KPR subsidi dan nonsubsidi. Akan tetapi, penelitian ini menganalisis bagaimana memaksimalkan profit KPR nonsubsidi dari PT X dimana pada saat ini pembangunan kedua KPR tersebut tidak jauh berbeda jika dilihat dari spesifikasinya. Melalui observasi dan wawancara dihasilkan data sumber daya yang dijadikan sebagai parameter untuk menyusun fungsi kendala dan tujuan. Terdapat 20 parameter sumber daya yang tersedia dengan tujuan untuk mencari 
keuntungan yang optimal dari usaha pembangunan KPR nonsubsidi seperti luas bangunan dan tanah, harga jual, keuntungan bruto, biaya produksi, ROI, waktu penyelesaian pembangunan, dan lain sebagainya. Data sumber daya tersebut akan dianalisis pada tahap selanjutnya, namun dilakukan analisis validasi data, mengidentifikasi data untuk permodelan sehingga secara matematis dapat dirumuskan model fungsi kendala dan tujuan. Urutan kegiatan tersebut dilakukan untuk persiapan simulasi dan komputasi dengan bantuan perangkat lunak QM. Perangkat lunak QM menyediakan berbagai modul salah satunya modulo linier programming yang digunakan untuk tahapan keempat yaitu tahapan penyelesaian dimana dalam hal ini dilakukan interpretasi hasil dari simulasi sebelumnya sehingga dapat mempermudah peneliti dalam mengambil suatu simpulan.

Linier programming merupakan metode untuk pemecahan masalah optimasi dan terdapat beberapa penelitian yang telah dilakukan menggunakan metode ini misalnya menentukan keuntungan maksimal dalam mengambil keputusan sewa kamar kos yang berkaitan dengan jumlah kapasitasnya [9], usaha produksi ice cream [10] dan produksi roti Fajar Bakeri [11]. Berdasarkan pendapat pihak sebagai objek penelitian tersebut mengemukakan bahwa terjadi perubahan yang signifikan antara jumlah keuntungan yang diperoleh sebelum dan sesudah menggunakan metode linier programming.

Kasus-kasus yang dapat diselesaikan dengan metode ini adalah kasus-kasus linier dan proses penyelesaiannya dilakukan secara iterasi [12] atau berulang-ulang sesuai aturan dalam linier programming sampai ditemukan adanya solusi optimal. Kasuskasus linier yang dimaksud misalnya pemrograman dinamik, teori antrian, teori persediaan, industri, perbankan, pendidikan dan lainlain. Oleh karena itu, ada beberapa syarat yang harus dipenuhi apabila menggunakan metode ini yaitu:

a. Kejelasan fungsi obyektif yang sesuai dengan solusi alternatif dari fungsi tujuan yang dapat dinyatakan sebagai fungsi linier misalnya solusi maksimasi atau minimasi

b. Sumber daya yang tersedia bersifat terbatas, dapat ditambahkan, dapat dibagi dan dapat disesuaikan secara proporsional

c. Variabel keputusan harus bernilai positif
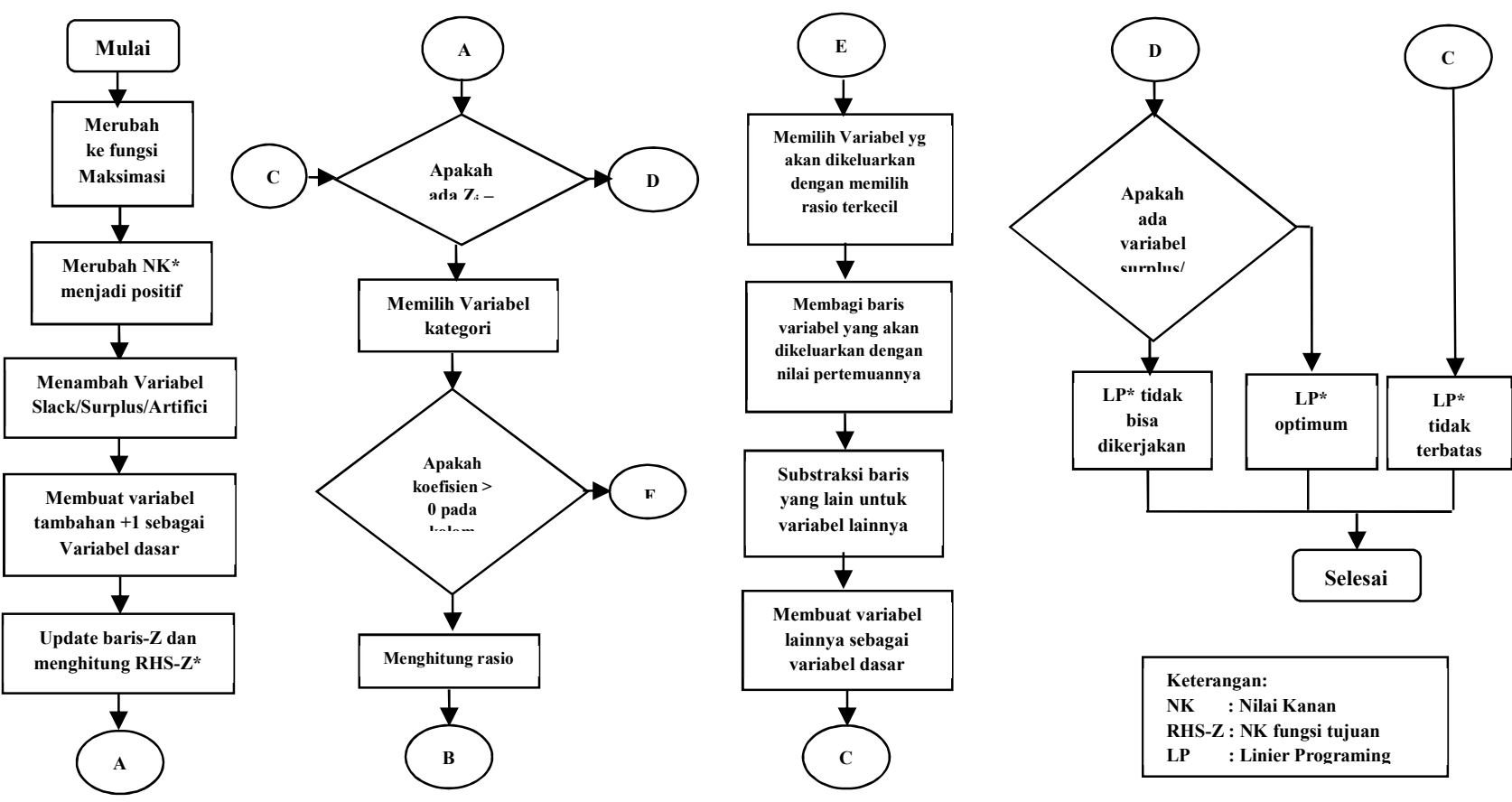

Gambar 2. Flowchart Metode Linier Programing

Selain memiliki syarat, linier programming memiliki sifat [13] atau karakter meliputi sifat linieritas, artinya sebanding atau konstan dalam hubungan setiap parameter dalam variabel keputusan relatif sama dengan nilai yang ada dalam fungsi. Sifat linieritas ini menghasilkan sifat proporsional, addivitas, divisibilitas dan kepastian dari fungsi tujuan dan kendala. Sifat proporsional mengukur nilai batas dari fungsi tujuan atau kendala terhadap nilai variabel. Misalnya, untuk setiap unit produk dianggap memiliki harga yang sama maka berapapun jumlah unit yang dibeli maka terpenuhi sifat proporsionalnya dan jika harga perunitnya tidak sama dalam artian harganya tergantung jumlah unit yang diproduksi maka sifat proporsionalnya tidak terpenuhi. Adapun sifat additivitas mengandung arti bahwa setiap fungsi kendala dan tujuan tidak terdapat bentuk perkalian silang pada model. 
Dengan kata lain, jika fungsi tujuan merupakan penambahan dari kontribusi variabel keputusan maka sifat additivitasnya terpenuhi dan jika fungsi kendala merupakan akumulasi dari variabelvariabel keputusan maka sifat additivitasnya juga terpenuhi. Sifat lainnya adalah divisibilitas dan kepastian dimana sifat disivibilitas menandakan bahwa nilai variabel keputusan noninteger bisa dioperasikan. Adapun sifat kepastian dimaksudkan bahwa parameter setiap model adalah konstan atau pasti dan bukan merupakan nilai peluang.

Gambar 2 menggambarkan alur linier programming yang melibatkan variabel lebih dari dua dan proses penyelesaiannya secara iterasi sampai ditemukan solusi dengan tiga kriteria yaitu linier programming dengan solusi tidak bisa dikerjakan, solusi optimal dan solusi tidak terbatas. Berdasarkan Gambar 2 terdapat lima langkah atau ketentuan yang bisa dijadikan sebagai algoritma dalam proses mencari solusi sesuai dengan fungsi tujuan. Adapun ketentuan tersebut dapat diuraikan sebagai berikut:

a. Langkah A, merupakan langkah awal dalam metode linier programming, akan tetapi sebelum menggunakan langkah ini terlebih dahulu dilakukan analisa sumber daya dan pembatasnya yang memenuhi sifat-sifat yang ada dalam metode ini. Apabila sifat-sifat tersebut terpenuhi, maka selanjutnya dilakukan pemodelan secara matematis meliputi fungsi kendala dan fungsi tujuan. Pada penelitian ini bertujuan untuk mengoptimalkan profit dari PT X dalam usaha KPR nonsubsidi dan memiliki beberapa fungsi kendala dan dilakukan proses selanjutnya sesuai tahapan pada langkah A, yaitu mengubah fungsi tujuan (Z) ke fungsi maksimasi yaitu merubah nilai kanan menjadi positif misalnya:

$Z=C_{1} X_{1}+C_{2} X_{2}+\cdots+C_{n} X_{n}$

Persamaan (1) diubah menjadi persamaan berikut:

$Z-C_{1} X_{1}+C_{2} X_{2}+\cdots+C_{n} X_{n}=0$

kemudian menambah variabel slack/surplus/artificial dan membuat variabel tambahan +1 sebagai variabel dasar. Selanjutnya dilakukan pembaruan baris fungsi $\mathrm{Z}$ dan menghitung nilai kanannya. Langkah ini juga digunakan untuk merubah fungsi kendala yang telah dimodelkan sebelumnya yaitu dengan mengubah tanda pertidaksamaan menjadi tanda persamaan sehingga dapat ditabulasikan sesuai Tabel 1.

Tabel 1. Tabel Langkah A pada Metode Linier programming

\begin{tabular}{|c|c|c|c|c|c|c|c|c|c|c|}
\hline $\begin{array}{c}\text { Variabel } \\
\text { dasar }\end{array}$ & $\mathbf{Z}$ & $\mathbf{X}_{1}$ & $\mathbf{X}_{2}$ & $\ldots$ & $\mathbf{X}_{\mathbf{n}}$ & $X_{n+1}$ & $X_{n+2}$ & $\ldots$ & $\mathbf{X}_{\mathbf{n}+\mathbf{m}}$ & $\begin{array}{c}\text { Nilai } \\
\text { Kanan }\end{array}$ \\
\hline $\mathrm{Z}_{\mathrm{i}}-\mathrm{C}_{\mathrm{i}}$ & 1 & $-\mathrm{C}_{1}$ & $-\mathrm{C}_{2}$ & $\ldots$ & $-\mathrm{C}_{\mathrm{n}}$ & 0 & 0 & $\ldots$ & 0 & 0 \\
\hline$X_{n+1}$ & 0 & & & & & & & $\ldots$ & 0 & $b_{1}$ \\
\hline$X_{n+2}$ & 0 & & & & & & & $\ldots$ & 0 & $\mathrm{~b}_{2}$ \\
\hline$\ldots$ & $\ldots$ & $\ldots$ & $\ldots$ & $\ldots$ & $\ldots$ & $\ldots$ & $\ldots$ & $\ldots$ & $\ldots$ & $\ldots$ \\
\hline$\ldots$ & $\ldots$ & $\ldots$ & $\ldots$ & $\ldots$ & $\ldots$ & $\ldots$ & $\ldots$ & $\ldots$ & $\ldots$ & $\ldots$ \\
\hline$X_{n+m}$ & 0 & $\mathrm{a}_{\mathrm{m} 1}$ & $\mathrm{a}_{\mathrm{m} 2}$ & $\ldots$ & $a_{m n}$ & 0 & 0 & $\ldots$ & 1 & $\mathrm{~B}_{\mathrm{m}}$ \\
\hline
\end{tabular}

b. Langkah $\mathrm{B}$, terdapat keputusan apakah lanjut ke langkah $\mathrm{C}$

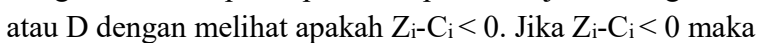
memilih variabel yang termasuk dalam kategori maksimasi kemudian dilakukan langkah E selanjutnya. Sebaliknya jika $\mathrm{Z}_{\mathrm{i}}-\mathrm{C}_{\mathrm{i}}>0$ atau $\mathrm{Z}_{\mathrm{i}}-\mathrm{C}_{\mathrm{i}}=0$ maka dilakukan langkah $\mathrm{C}$ dan $\mathrm{D}$

c. Langkah $\mathrm{C}$, apabila pada langkah $\mathrm{B}$ tidak ditemukan $\mathrm{Z}_{\mathrm{i}}-\mathrm{C}_{\mathrm{i}}<$ 0 maka kasus ini memiliki solusi tidak terbatas.

d. Langkah D, apabila pada langkah B tidak ditemukan $\mathrm{Z}_{\mathrm{i}}-\mathrm{C}_{\mathrm{i}}<$ 0 maka dalam hal ini dilakukan pengecekan terhadap keberadaan variabel surplus/artificial. Jika variabel surplus atau artificial lebih besar dari 0 maka kasusu ini tidak bisa dikerjakan menggunakan linier programming. Sebaliknya jika variabel tersebut ada, maka ditemukan solusi yang optimal.

e. Langkah $\mathrm{E}$, jika pada langkah $\mathrm{B}$ ditemukan $\mathrm{Z}_{\mathrm{i}}-\mathrm{C}_{\mathrm{i}}<0$ maka dipilih variabel kategori dengan melihat rasio terkecil dari perbandingan nilai kanan dengan nilai pertemuannya dan melakukan substraksi pada baris lainnya dan membuat variabel tersebut sebagai variabel dasar.

\section{HASIL DAN PEMBAHASAN}

Ada beberapa perbedaan yang terlihat dalam pembangunan perumahan subsidi dan nonsubsidi yaitu perbedaan dari segi harga jual, fasilitas, KPR (Kredit Pemilikan Rumah), spesifikasi, tipe bangunan, lokasi, renovasi dan harga jual kembali. Jika dilihat dari harga jual, perumahan nonsubsidi diperuntukkan untuk masyarakat yang memiliki jumlah penghasilan diatas ratarata dan mampu membayar jumlah bunga yang telah ditetapkan oleh bank. Hal ini disebabkan karena suku bunga dari pembayaran kredit (KPR) ditentukan bank pemberi kredit berdasarkan perubahan kenaikan dollar. Dari segi fasilitas yang ditawarkan, pembangunan rumah nonsubsidi dilengkapi dengan dapur dan ukuran ruangan yang lebih luas dan lain sebagainya.

Dalam kasus ini, pengembang PT X menyediakan tiga tipe rumah nonsubsidi dengan ukuran bangunan dan luas tanah yang berbeda-beda yaitu tipe A ukuran 40/100, tipe B ukuran 70/200 dan tipe $C$ dengan ukuran 200/350 dengan alokasi sumber daya yang tersedia sebagai berikut: 
Tabel 2. Sumber Daya Pengembangan Perumahan Nonsubsidi

\begin{tabular}{|c|c|c|c|c|}
\hline \multirow[t]{2}{*}{ No } & \multirow[t]{2}{*}{ Uraian } & \multicolumn{3}{|c|}{ Tipe Rumah KPR Nonsubsidi } \\
\hline & & Tipe A & Tipe B & Tipe C \\
\hline 1 & Luas Bangunan (m2) & 40 & 70 & 200 \\
\hline 2 & Luas Tanah (m2) & 100 & 200 & 350 \\
\hline 3 & Harga Produksi (Rp) & $70 \%$ & $70 \%$ & $70 \%$ \\
\hline 4 & Harga Jual (Rp) & 400 juta & 800 juta & $2,7 \mathrm{M}$ \\
\hline 5 & Keuntungan bruto (Rp) & $20 \%$ & $20 \%$ & $20 \%$ \\
\hline 6 & Listrik (W/V) & 1300 & 2400 & 5500 \\
\hline 7 & Jumlah Lantai & 1 & 1 & 2 \\
\hline 8 & Ruang Tidur Utama & $1(3 \times 3)$ & $1(3 \times 3)$ & $1(3 \times 4)$ \\
\hline 9 & Ruang Tidur & $1(3 \times 3)$ & $1(3 \times 3)$ & $3(3 \times 3)$ \\
\hline 10 & Kamar mandi & $1(1.5 \times 1.5)$ & $1(1.5 \times 1.5)$ & $3(1 \times 1.25)$ \\
\hline 11 & Dapur & $1(1.5 \times 2)$ & $1(1.5 \times 2)$ & $1(13 \times 3)$ \\
\hline 12 & Ruang Tamu & $1(3 \times 3)$ & $1(3 \times 3)$ & $1(3 \times 4)$ \\
\hline 13 & PDAM & ya & ya & ya \\
\hline 14 & Tempat Ibadah & opsional & opsional & opsional \\
\hline 15 & Taman Olahraga & opsional & opsional & opsional \\
\hline 16 & Lebar Jalan (m) & $7 / 9$ & $7 / 9$ & $7 / 9$ \\
\hline 17 & Lokasi dari Tempat Umum (m) & $1 \mathrm{~km}$ & $1 \mathrm{~km}$ & $1 \mathrm{~km}$ \\
\hline 18 & Kelebihan tanah (m) & 100 & - & - \\
\hline 19 & ROI (Laba atas investasi/ \%) & $15 \%$ & $15 \%$ & $15 \%$ \\
\hline 20 & Tanah Makam (m2) & opsional & opsional & opsional \\
\hline
\end{tabular}

Tabel 2 menunjukkan terdapat 20 parameter yang akan dianalisis untuk mencari optimalisasi keuntungan dari pengembangan perumahan nonsubsidi PT X. Adapun alokasi sumber daya dari fungsi pembatas dapat ditabulasikan seperti Tabel 3 dibawah ini:

Tabel 3. Fungsi Pembatas Alokasi Sumber Daya Perumahan Nonsubsidi

\begin{tabular}{clccc}
\hline No & Uraian & \multicolumn{3}{c}{ Batasan } \\
\hline $\mathbf{1}$ & Luas lahan $\left(\mathrm{m}^{2}\right)$ & 7142.857143 & 14285.71429 & 25000 \\
\hline $\mathbf{2}$ & Biaya produksi (Rp) & $80 \%$ & $80 \%$ & $80 \%$ \\
\hline $\mathbf{3}$ & Waktu Pelaksanaan & 3 bulan & 3 bulan & 3 bulan \\
\hline $\mathbf{4}$ & Permintaan pasar & $300 \%$ & $300 \%$ & $300 \%$ \\
\hline
\end{tabular}

Fungsi pembatas yang disebutkan pada Tabel 6 digunakan sebagai standard untuk menyatakan pertidaksamaan dalam model matematik dari alokasi sumber daya yang tersedia.

Adapun model dari fungsi kendala dalam pengembangan perumahan nonsubsidi adalah sebagai berikut:

1. Batasan luas lahan $\left(\mathrm{m}^{2}\right)$
PT X menawarkan tiga tipe perumahan nonsubsidi yang diperjualbelikan ke masyarakat yaitu tipe A (40/100), B (70/200) dan tipe C (200/350) dengan batasan luas tanah masing-masing tipe secara berurutan adalah $7142 \mathrm{~m}^{2}, 14285$ $\mathrm{m}^{2}$ dan $25000 \mathrm{~m}^{2}$ sehingga secara matematis bentuk model dari batasan luas tanah adalah sebagai berikut:

$100 X_{1} \leq 7142$ 
$200 X_{2} \leq 14285$

$$
350 X_{3} \leq 25000
$$

dimana variabel $X_{1}$ untuk tipe $\mathrm{A}, X_{2}$ tipe B dan $X_{3}$ tipe C.

2. Batasan biaya produksi (Rp)

PT X memberikan batasan biaya pembangunan perumahan sebesar $80 \%$ dari harga jual yang telah ditetapkan. Berdasarkan Tabel 2 harga jual untuk rumah tipe A sebesar 400 juta, tipe B sebesar 800 juta dan tipe $\mathrm{C}$ sebesar 2,7 miliar sehingga secara matematis model matematika dari batasan biaya produksi perumahan nonsubsidi adalah:

$$
\begin{aligned}
& 280 X_{1} \leq 320 \\
& 560 X_{2} \leq 640 \\
& 350 X_{3} \leq 2160
\end{aligned}
$$

3. Batasan waktu pelaksanaan (hari)

Pembangunan perumahan nonsubsidi memerlukan waktu selama 3 bulan, oleh sebab itu, model matematisnya sebagai berikut:

$X_{1}+X_{2}+X_{3} \leq 90$

4. Batasan permintaan pasar

Batasan permintaan pasar dimaksudkan untuk melihat seberapa besar permintaan masyarakat terhadap pembangunan perumahan yang telah ditetapkan oleh pengembang. Oleh sebab itu, berdasarkan data yang telah ditabulasikan dalam Tabel 5 maka secara matematis model dari permintaan pasar dari pengembangan perumahan PT X adalah sebagai berikut:

$X_{1}+X_{2}+X_{3} \leq 3$

\section{Batasan ROI}

ROI disebut sebagai laba yang diperoleh atau hilang pada saat investasi dan dinyatakan sebagai persentasi dengan besaran yang relative terhadap jumlah uang yang diinvestasikan. Adapun model matematisnya yaitu:

$X_{1}+X_{2}+X_{3} \leq 15$

Persamaan (3) - (11) merupakan fungsi kendala yang telah dimodelkan dalam bentuk pertidaksamaan berdasarkan sumber daya yang tersedia dan pembatasnya. Adapun fungsi tujuan dari permasalahan ini yaitu PT $\mathrm{X}$ ingin memperoleh keuntungan sebesar $20 \%$ untuk setiap tipe rumah yang dibangun yaitu:

Maksimumkan:

$Z=80 X_{1}+160 X_{2}+540 X_{3}$

Langkah selanjutnya setelah pembentukan model dari fungsi kendala dan tujuan dilakukan analisis simulasi menggunakan QM. Hasil simulasi tersebut digunakan sebagai pengambilan keputusan PT X dalam memanajemen usahanya sehingga PT X mampu bersaing dengan para pengembang perumahan dengan memperhatikan sumber daya untuk memperoleh keuntungan atau profit secara maksimal.

Berdasarkan hasil simulasi QM dengan melakukan inputan yang sesuai dengan persamaan (7) - (16) maka diperoleh:

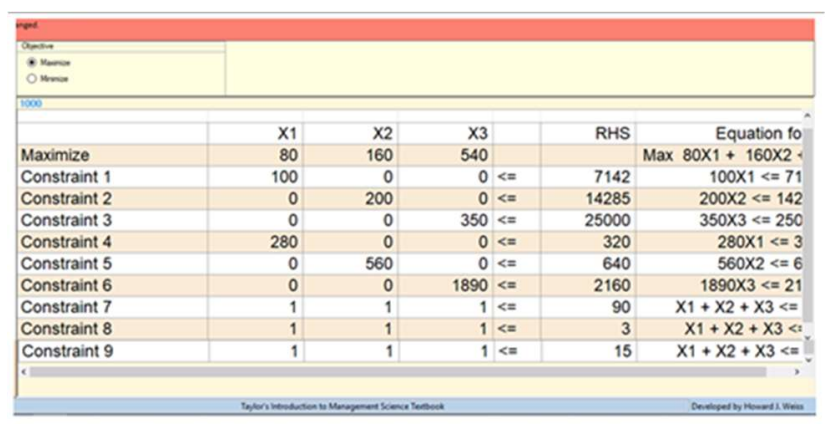

Gambar 3. Interface Model Fungsi Kendala dan Tujuan Perumahan Nonsubsidi

Gambar 3 menunjukkan teradapat 9 constraint atau kendala yang telah dirumuskan beradasarkan model data dari Tabel 2 dan Tabel 3 , selanjutnya dianalisis menggunakan linier programming

\begin{tabular}{|c|c|c|c|c|c|}
\hline$x_{n=1}$ & \multicolumn{5}{|c|}{ 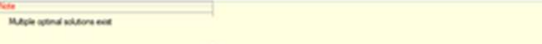 } \\
\hline 1000 sothen & $\mathrm{x}_{1}$ & X2 & $x_{3}$ & & RHS \\
\hline Maximize & 80 & 160 & 540 & & \\
\hline Constraint 1 & 100 & 0 & 0 & $<$ & 7142 \\
\hline Constraint 2 & 0 & 200 & 0 & $<=$ & 14285 \\
\hline Constraint 3 & 0 & 0 & 350 & $<=$ & 25000 \\
\hline Constraint 4 & 280 & 0 & 0 & $<=$ & 320 \\
\hline Constraint 5 & 0 & 560 & 0 & $<$ & 640 \\
\hline Constraint 6 & 0 & 0 & 1890 & $<$ & 2160 \\
\hline Constraint 7 & 1 & 1 & 1 & $<$ & 90 \\
\hline Constraint 8 & 1 & 1 & 1 & $<=$ & 3 \\
\hline Constraint 9 & 1 & 1 & 1 & $<$ & 15 \\
\hline Solution &, 71 & 1,14 & 1,14 & & 857,14 \\
\hline
\end{tabular}
dengan fungsi tujuan untuk mencari optimalisasi dari profit yang akan diperoleh. Secara iterasi sebanyak empat kali menggunakan bantuan perangkat lunak QM diperoleh:

Gambar 4. Linier Programing Result Perumahan Nonsubsidi

Berdasarkan Gambar 4 di atas dapat menunjukkan bahwa hasil simulasi menggunakan linier programming dengan bantuan perangkat lunak QM adalah dihasilkan solusi $X_{1}=0,71$, $X_{2}=1,14$ dan $X_{3}=1,14$ dengan $\mathrm{RHS}=854,14$ artinya untuk memperoleh keuntungan yang maksimal maka PT X sebaiknya membangun tipe rumah A sebanyak 71 unit, tipe rumah $\mathrm{B}$ dan tipe rumah $\mathrm{C}$ masing-masing sebanyak 114 unit sehingga keuntungan yang maksimal diperoleh sejumlah Rp. 857.140.000.

\section{DAFTAR PUSTAKA}

[1] Tim Penyusun Buku. "Nusa Tenggara Barat Dalam Data 2015". Bappeda: Provinsi Nusa Tenggara Barat. 2015.

[2] Dewa Ketut Sudarsana. “Optimasi Jumlah Tipe Rumah yang Akan Dibangun Dengan Metode Simpleks Pada Proyek Pengembangan Perumahan". Jurnal Ilmiah Teknik Sipil Volume 13 Nomor 2 Juli 2009.

[3] Peraturan Pemerintah Republik Indonesia Nomor 14 Tahun 2016 Tentang Penyelenggaraan Perumahan dan Kawasan Permukiman

[4] Anonim." 8 Perbedaan Rumah Subsidi dan Non subsidi: $\quad$ https://rumahlia.com/tips-trik/infodasar/perbedaan-rumah-subsidi-dan-non-subsidi, November 30, 2017 [Nov. 02, 2018]

https://doi.org/10.25077/ TEKNOSI.v5i2.2019.104-111 
[5] Desi Vita Sari Sinaga." Optimalisasi Keuntungan Penjualan Roti Dengan Metode Branch And Bound (Studi Kasus: UD. Akbar Jaya)". Skripsi, Universitas Sumatera Utara, Medan, 2018.

[6] Dewa Ketut Sudarsana. "Optimasi Jumlah Tipe Rumah yang Akan Dibangun Dengan Metode Simpleks Pada Proyek Pengembangan Perumahan". Jurnal Ilmiah Teknik Sipil Volume 13 Nomor 2 Juli 2009.

[7] Reni Febri Utari dan Andi SA.”Optimalisasi jumlah produksi tipe rumah pada proyek pengembangan perumahan dengan menggunakan metode Simplek (studi kasus: PT Araya Bumi Malang)". Media Teknik Sipil, Volume 10 Nomor 2, Agustus 2012, pp: 174-182.

[8] Uswatun Hasanah dan Ahmad." Linier Programing dalam Manajemen Keuntungan Proyek Perumahan Subsidi",'Prosiding SENTIA, 2018, pp. 7-11

[9] Citra, P. "Optimasi Pendapatan Sewa Kamar Dengan Menggunakan Metode Simpleks (Studi kasus : Inna Simpang Surabaya), Tugas Akhir, Universitas Negeri Malang, Malang, 2006.

[10] Hamdy, A.Taha .’Riset Operasi”. Jakarta : Binarupa Aksara. 1996.

[11] Setiawati, F." Optimasi produksi di Fajar Bakery dengan penerapan pemrogaman linier menggunakan metode simpleks primal", Tugas Akhir, Universitas Kristen Petra, 2004.

[12] Jong Jek Siang. "Riset Operasi dalam Pendekatan Algoritmis". Yogyakarta: Andi Offset. 2011.

[13] Siringoringo, Hotniar. "Seri Teknik Riset Operasional. Pemrograman Linear". Yogyakarta : Graha Ilmu. 2005 